ISSN: 2302-8556

E-Jurnal Akuntansi Universitas Udayana

Vol.23.1. April (2018): 240-266

DOI: https://doi.org/10.24843/EJA.2018.v23.i01.p10

\title{
Kompetensi dan Moral Reasoning Memoderasi Pengaruh Independensi Pada Kualitas Audit di Kantor Akuntan Publik Provinsi Bali
}

\author{
Ni Putu Ellis Yulinda Dewi ${ }^{1}$ \\ A.A.N.B. Dwirandra ${ }^{2}$ \\ ${ }^{1}$ Fakultas Ekonomi dan Bisnis Universitas Udayana (Unud), Bali, Indonesia \\ email: yulindaelisputu@gmail.com/ Telp: 089631405114 \\ ${ }^{2}$ Fakultas Ekonomi dan Bisnis Universitas Udayana (Unud), Bali, Indonesia
}

\begin{abstract}
ABSTRAK
Tujuan penelitian ini adalah menganalisis kompetensi dan moral reasoning memoderasi pengaruh independensi terhadap kualitas audit pada Kantor Akuntan Publik Provinsi Bali. Penelitian ini dilakukan di seluruh kantor Kantor Akuntan Publik di Bali sebanyak tujuh kantor yang terdapat pada Wilayah Bali tahun 2017 dengan menjadikan auditor sebanyak 73 orang sebagai sampel dengan metode sample jenuh. Pengumpulan data dilakukan dengan menyebarkan kuesioner dengan 47 responden yang kembali dan layak digunakan sedangkan sebanyak 26 digugurkan di uji melalui moderasi regresi analisis (MRA). Berdasarkan hasil analisis, independensi berpengaruh positif signifikan terhadap kualitas audit pada Kantor Akuntan Publik Di Bali. Kompentensi memperkuat berpengaruh positif independensi terhadap kualitas audit pada Kantor Akuntan Publik Di Bali. Moral reasoning memperkuat berpengaruh positif independensi terhadap kualitas audit pada Kantor Akuntan Publik Di Bali.

Kata kunci: Independensi, kompetensi, moral reasoning, kualitas audit.
\end{abstract}

\begin{abstract}
The purpose of this study is to analyze the competence and moral reasoning to moderate the influence of independence on audit quality at the Public Accounting Firm of Bali Province. This research was conducted in all offices of Public Accounting Firm in Bali as many as seven offices located in Bali Region 2017 by making auditor as much as 73 people as sample with saturated sample method. Data collection was done by distributing questionnaires with 47 respondents who were re-eligible and used while 26 were aborted in the test through moderation regression analysis (MRA). Based on the results of the analysis, independence has a significant positive effect on audit quality at Public Accounting Firm in Bali. Competence strengthens positively affects the independence of audit quality at Public Accounting Firm In Bali. Moral reasoning strengthens the positive impact of independence on audit quality at Public Accounting Firm in Bali.
\end{abstract}

Keywords: Independence, competence, moral reasoning, audit quality.

\section{PENDAHULUAN}

Laporan keuangan yang merupakan tanggung jawab manajemen perlu diaudit oleh akuntan publik sebagai pihak ketiga yang independen di luar perusahaan untuk 
menghindari kesalahan yang terjadi, baik yang disengaja maupun tidak disengaja. Profesi akuntan publik merupakan profesi kepercayaan masyarakat yang mengharapkan penilaian yang bebas dan tidak memihak dalam melaksanakan audit terhadap informasi yang disajikan oleh manajemen perusahaan dalam laporan keuangan (Mulyadi, 2002:2). Audit merupakan proses yang sistematik, independen dan terdokumentasi untuk memperoleh bukti audit dan mengevaluasinya secara objektif untuk menentukan sampai sejauh mana kriteria audit dipenuhi (Yunita dan Leny, 2015). Perusahaan harus semakin kritis dalam memilih Kantor Akuntan Publik (KAP) untuk mengaudit laporan keuangan perusahaan. Selain digunakan oleh perusahaan, hasil dari audit juga dapat digunakan oleh pihak luar perusahaan seperti calon investor, investor, kreditor, Bapepam dan pihak lain yang terkait untuk menilai perusahaan dan mengambil keputusan-keputusan yang strategik yang berhubungan dengan perusahaan tersebut (Nizarul et. al., 2007). Dalam hal ini akuntan publik berfungsi sebagai pihak ketiga yang menghubungkan manajemen perusahaan dengan pihak luar perusahaan yang berkepentingan (Novyarni, 2014).

Yunita dan Leny (2015) menyatakan saat ini tantangan profesi akuntansi semakin kompetitif dengan diberlakukannya Masyarakat Ekonomi ASEAN pada tahun 2015. Akuntan Indonesia harus menghadapi persaingan dengan akuntan asing untuk menawarkan jasa profesinya. Pemerintah Indonesia bersama dengan seluruh anggota Negara-negara Asia Tenggara yang tergabung dalam ASEAN sudah menyepakati pemberlakukan MEA pada tahun 2015. Secara sederhana MEA dapat 
ISSN: 2302-8556

E-Jurnal Akuntansi Universitas Udayana

Vol.23.1. April (2018): 240-266

diartikan pasar bebas untuk wilayah ASEAN. Salah satu bidang jasa yang diberlakukan secara bebas adalah jasa profesi akuntansi, untuk itu pemerintah telah menyiapkan berbagai perangkat peraturan untuk menjamin adanya persiangan yang sehat dalam penyediaan jasa profesi akuntansi (Malem dan Primsa, 2013). Pemberlakuan MEA juga memberikan konsekuensi positif maupun negatif bagi profesi akuntan di Indonesia.

De Angelo (1981) dalam Badjuri (2011: 123) menyatakan kualitas audit dikatakan sebagai keadaan dimana seorang auditor dapat menemukan dan melaporkan ketidaksesuaian terhadap prinsip yang terjadi pada laporan akuntansi kliennya. Salah satu pendekatan yang digunakan adalah pendekatan yang berorientasi hasil (outcome oriented) dan pendekatan yang berorientasi proses (process oriented) (Greg and Graham, 2013). Sebagai penunjang keberhasilan dalam menjalankan tugas dan fungsinya dengan baik, sangatlah diperlukan kualitas audit (Badjuri, 2011). Kemampuan auditor untuk membuat keputusan yang akan diambil ketika menghadapi situasi yang dilemma, kompetensi akan sangat bergantung kepada berbagai hal, karena keputusan yang diambil oleh auditor juga akan banyak berpengaruh kepada perusahaan (Badir and Abeer, 2013). Auditor harus mengidentifikasi, menganalisis, mengevaluasi, dan mencatat informasi yang memadai untuk mencapai tujuan penugasan dalam membuat laporan hasil audit (Kenneth and Jeffrey, 2007). 
Terkait permasalahan audit, melalui persepsi teori keagenan memperlihatkan bahwa permintaan jasa audit muncul karena adanya konflik kepentingan antara manajemen sebagai agen dan pemegang saham sebagai principal, dan pihak-pihak lain yang mengadakan kontrak dengan klien (Adnyani et al., 2014). Auditor dalam hal ini merupakan pihak yang dianggap mampu menjembatani kepetingan principal dan agen dalam mengelola keuangan perusahaan (Novyarni, 2014).

Kualitas audit dapat ditingkatkan dengan kompetensi dan independensi yang dimiliki auditor dalam penerapannya akan terkait dengan pendidikan dan pengalaman memadai yang dimiliki auditor dalam bidang auditing dan akuntansi (Nizarul et al., 2007). Dalam melaksanakan audit, auditor harus bertindak sebagai seorang yang ahli di bidang akuntansi dan auditing. Pencapaian keahlian dimulai dengan pendidikan formal, yang selanjutnya diperluas melalui pengalaman dalam praktik audit. Selain itu, auditor harus menjalani pelatihan teknis yang cukup yang mencakup aspek teknis maupun pendidikan umum (Syamsuddin et al., 2014). Untuk mencapai kompetensinya harus memperoleh pengalaman profesionalnya dengan mendapatkan supervisi memadai dan review atas pekerjaannya dari atasan yang lebih berpengalaman.

Kualitas audit sangat besar kaitannya dengan moral reasoning, Alan (2015) menjelaskan bahwa tingkat perkembangan moral reasoning seseorang dipengaruhi oleh tiga hal, yaitu umur, tingkat pendidikan dan kondisi lingkungan. Auditor dengan usia yang lebih dewasa, akan lebih bijak dalam mengambil suatu keputusan, sehingga 
ISSN: 2302-8556

audit judgement yang dibuat bisa lebih tepat dan berkualitas. Selain itu moral reasoning seseorang juga akan ditentukan oleh tingkat pendidikannya. Semakin tinggi tingkat pendidikan seseorang, maka penalaran yang dimilikinya dalam memecahkan setiap problem yang dihadapinya akan semakin baik, sehingga audit yang dijalankan dapat lebih berkualitas. Moral reasoning auditor juga akan dipengaruhi oleh kondisi lingkungan. Auditor yang hidup dalam lingkungan yang baik, akan bertindak sesuai dengan kode etik yang berlaku, dan terhindar dari perilaku disfungsional auditor yang dapat menurunkan kualitas audit.

Menurut Toufan (2014) moral reasoning didefinisikan sebagai alasan yang mendasari seseorang dalam melakukan suatu tindakan atau alasan yang mendasari seseorang dalam membenarkan ataupun mengkritik suatu perbuatan. Seorang auditor yang memiliki moral reasoning yang tinggi, akan lebih tepat dalam melakukan audit judgement, sehingga kualitas audit yang dihasilkan juga akan semakin baik. Penelitian Ceacilia et al. (2015) menemukan bahwa moral reasoning mampu memperkuat pengaruh positif dan signifikan independensi terhadap kualitas audit. Sama dengan hasil penelitian yang dilakukan oleh Suriana (2014) serta Indira (2015) yang menyimpulkan bahwa variabel moral reasoning mampu memperkuat pengaruh positif dan signifikan independensi pada kualitas audit.

Kualitas audit ditentukan oleh tiga hal yaitu kompetensi, independensi dan moral reasoning seorang auditor (Paneeda \& Phaprukbaramee, 2015). Nila (2014) menyatakan audit merupakan suatu proses pemeriksa independen memeriksa laporan 
keuangan suatu organisasi untuk memberikan suatu pendapat mengenai kewajaran dan kesesuaiannya dengan prinsip akuntansi yang berlaku umum yang dalam penulisan selanjutnya ditulis sebagai opini audit. Adanya hubungan kompetensi, moral reasoning pada independensi dengan kualitas audit menyebabkan kompetensi, moral reasoning diduga dapat memoderasi hubungan independensi dalam memengaruhi kualitas audit.

Melalui pemaparan masalah yang telah dijabarkan, maka dapat dirumuskan masalah penelitian yaitu (1) Apakah independensi berpengaruh pada kualitas audit KAP di Bali, (2) Apakah kompetensi memoderasi pengaruh independensi pada kualitas audit KAP di Bali, (3) Apakah moral reasoning memoderasi pengaruh independensi pada kualitas audit KAP di Bali.

Teori Keagenan

Teori keagenan menjelaskan hubungan antara agent (pihak manajemen suatu perusahaan) dengan principal (pemilik). Hubungan agensi ada ketika salah salah satu pihak (principal) menyewa pihak lain (agent) untuk melaksanakan suatu jasa, dan dalam hal itu, mendelegasikan wewenang untuk membuat keputusan kepada agen tersebut (Anthony dan Govindarajan, 2005:269). Principal merupakan pihak yang memberikan amanat kepada agent untuk melakukan suatu jasa atas nama principal, sementara agent adalah pihak yang menerima mandat, dengan demikian dapat disimpulkan agent bertindak sebagai pihak yang mengevaluasi informasi (Putri dan Nur, 2013). 
ISSN: 2302-8556

E-Jurnal Akuntansi Universitas Udayana

Vol.23.1. April (2018): 240-266

\section{Cognitive Development Theory}

Ceacilia et al. (2015) menyatakan Cognitive Development Theory (CDT) memfokuskan pada perkembangan kognitif dari struktur penalaran (reasoning) yang mendorong/menyebabkan seseorang membuat sebuah keputusan moral. Menurut perspektif CDT, perkembangan moral menjadi lebih rumit dan sukar karena terkait dengan struktur-struktur dari perkembangan moral itu sendiri. Kohlberg (1958) dalam Toufan (2014) mengidentifikasi 3 level perkembangan moral yaitu: pre-conventional level, conventional level dan post conventional level yang di bentuk dalam 6 tahapan (six stages).

Profesi Auditor

Auditor adalah seorang yang memiliki kualifikasi tertentu dalam melakukan audit atas laporan keuangan dan kegiatan suatu perusahaan atau organisasi. Menurut Mulyadi (2002) auditor dapat dibedakan menjadi tiga jenis, antara lain. Auditor pemerintah adalah auditor yang bertugas melakukan audit atas keuangan Negara pada instansi-instansi pemerintah. Di Indonesia audit ini dilakukan oleh Badan Pemeriksaan Keuangan (BPK).

Eksternal auditor atau akuntan public adalah seorang praktisi dan gelar professional yang diberikan kepada akuntan di Indonesia yang telah mendapat izin untuk memberikan jasa audit umum dan review atas laporan keuangan, audit kinerja, dan audit khusus serta jasa nonassurancce seperti jasa konsultasi, jasa kompilasi, jasa perpajakan. Jasa-jasa yang ditawarkan oleh akuntan publik ini dilakukan pada 
perusahaan terbuka, yaitu perusahaan yang go public, perusahaan-perusahaan besar dan juga perusahaan kecil serta organisasi yang tidak bertujuan mencari laba. Praktik akuntan publik harus dilakukan melalui suatu Kantor Akuntan Publik (KAP). Internal auditor merupakan auditor yang bekerja suatu perusahaan dan oleh karenanya berstatus sebagai pegawai pada perusahaan tersebut. Tugas utamanya ditujukan untuk membantu manajemen perusahaan tempat dimana ia bekerja.

Kompentensi

Kompetensi dapat diartikan sebagai kemampuan seseorang dalam menghadapi situasi dan keadaan didalam pekerjaannya. Kompetensi seseorang dapat dilihat dari tingkat kreativitas yang dimilikinya serta inovasi-inovasi yang diciptakan dan kemampuannya dalam menyelesaikan suatu masalah (Novyarni, 2014). Kompetensi didefinisikan sebagai aspek-aspek pribadi dari seorang pekerja yang memungkinkan dia untuk mencapai kinerja superior. Aspek-aspek pribadi ini mencakup sifat, motifmotif, sistem nilai, sikap, pengetahuan dan ketrampilan dimana kompetensi akan mengarahkan tingkah laku, sedangkan tingkah laku akan menghasilkan kinerja (Kamus Kompetensi LOMA (1998) dalam Dwi et al. (2015).

Independensi

Mautz dan Sharaf (1993:246) dalam Ari (2010) Independensi merupakan suatu tindakan baik sikap perbuatan atau mental auditor dalam sepanjang pelaksanaan audit dimana auditor dapat rnemposisikan dirinya dengan auditee nya secara tidak memihak dan dipandang tidak memihak oleh pihak-pihak yang berkepentingan 
ISSN: 2302-8556

terhadap hasil auditnya. Independen berarti auditor tidak mudah dipengaruhi. Auditor tidak dibenarkan memihak kepentingan siapapun. Auditor berkewajiban untuk jujur tidak hanya kepada manajemen dan pemilik perusahaan, namun juga kepada kreditur dan pihak lain yang meletakkan kepercayaan atas pekerjaan auditor (Antle, 1984 dalam Nizarul et al., 2007). Auditor secara intelektual harus jujur, bebas dari kewajiban terhadap kliennya, dan tidak mempunyai kepentingan dengan klien baik terhadap manajemen maupun pemilik (IAI, 2001: Seksi 220).

Moral Reasoning

Menurut Gaffikin \& Lindawati (2012) dalam Ceacilia et al. (2016) moral reasoning didefinisikan sebagai alasan yang mendasari seseorang dalam melakukan suatu tindakan atau alasan yang mendasari seseorang dalam membenarkan ataupun mengkritik suatu perbuatan. Dalam hal ini alasan moral diperoleh dari proses pembelajaran dan penalaran ilmiah yang dilakukan seseorang (auditor). Bentukbentuk alasan moral terlihat dari perilaku yang diperlihatkan didalam bekerja seperti jujur dan bekerja sesuai dengan hati nurani dan sumpah jabatan. Ketika pertimbangan moral telah dilaksanakan dengan baik dalam membuat setiap keputusan, maka mutu pekerjaan yang dilaksanakan akan semakin membaik (Paneeda \& Phaprukbaramee, 2015).

Kualitas Audit

Kualitas audit merupakan kemampuan dari seorang auditor dalam melaksanakan tugasnya, dimana dalam melakukan audit seorang auditor dapat 
menemukan kesalahan klien dan melaporkannya. De Angelo (1981) dalam Badjuri (2011: 123) kualitas audit adalah probabilitas dimana auditor akan menemukan dan melaporkan tentang adanya suatu pelanggaran dalam sistem akuntansi kliennya. Seorang akuntan publik dalam menjalankan tugas auditnya harus berpegang pada Standar Profesional Akuntan Publik (SPAP) yang berlaku, harapannya audit dapat mengurangi ketidakselarasan kepentingan antara manajemen dan para pemegang saham. Dengan dipatuhinya standar dan prinsip yang berlaku, sehingga tujuan yang inginkan akan tercapai yaitu audit yang berkualitas (Novyarni, 2014).

Pentingnya aspek independensi bagi berlangsungnya proses audit dan banyaknya keraguan masyarakat mengenai independensi auditor, telah mendorong banyak pakar akuntansi dan pengauditan untuk melakukan penelitian mengenai independensi auditor (Ari, 2010). Nizarul et al. (2007) yang melakukan penelitian tentang hubungan antara independensi dengan pendapat hasil audit menyimpulkan bahwa auditor yang independen memberikan pendapat hasil audit lebih tepat dibandingkan auditor yang tidak independen.

Hasil penelitian Nizarul et al. (2007) menunjukkan bahwa independensi berpengaruh positif terhadap kualitas audit. Hasil penelitian Ari (2010) membuktikan hal yang sama dimana kualitas audit dipengaruhi secara positif oleh sikap independensi seorang auditor. Hal ini dipertegas oleh Nila (2014) dalam penelitiannya menemukan bahwa seorang auditor yang memiliki sikap independensi 
ISSN: 2302-8556

mampu memberikan kualitas pada hasil laporan audit. Dari penjelasan di atas, maka hipotesis yang dapat dirumuskan adalah sebagai berikut.

$\mathrm{H}_{1}$ : independensi berpengaruh positif pada kualitas audit.

Pada Standar Profesional Akuntan Publik tercantum bahwa untuk memenuhi persyaratan sebagai seorang profesional, auditor harus memiliki kompetensi (Sari, 2012). Dari pernyataan tersebut dapat dikatakan bahwa kompetensi merupakan hal mutlak yang harus dimiliki oleh auditor. Alan (2015) menyatakan kompetensi adalah kualifikasi yang dibutuhkan oleh auditor untuk melakukan audit dengan benar. Semakin banyak kompetensi yang dimiliki oleh auditor maka semakin meningkat pula kualitas audit yang dihasilkannya. Kompetensi menjadikan auditor lebih peka dan lebih dapat melakukan penilaian dalam pengambilan keputusan secara tepat sehingga data-data ataupun hasil audit yang diambil oleh auditor dapat diandalkan oleh para pemakai hasil audit tersebut (Ikha, 2015).

Hasil penelitian Nizarul et al. (2007) menunjukkan secara empiris bahwa faktor kompetensi mampu memperkuat hubungan independensi terhadap kualitas audit. Hasil penelitian Yunita dan Leny (2015) membuktikan hal yang sama dimana kualitas audit dipengaruhi secara positif oleh independensi yang dimoderasi oleh kompetensi yang dimiliki auditor. Abdul et al. (2014) menemukan bukti empiris bahwa kompetensi yang dimiliki oleh seorang auditor mampu memperkuat pengaruh independensi pada kualitas audit. Dari penjelasan di atas, maka hipotesis yang dapat dirumuskan adalah sebagai berikut: 
$\mathrm{H}_{2}$ : kompetensi memperkuat pengaruh positif independensi pada kualitas audit.

Auditor bertanggung jawab dalam pelaksanaan audit serta mendapatkan dan mengevaluasi bukti mengenai asersi tentang kegiatan-kegitan dan kejadian-kejadian ekonomi untuk meyakinkan tingkat keterkaitan antara asersi tersebut dengan kriteria yang telah ditetapkan melalui kualitas auditor untuk merencanakan dan melaksanakan auditnya dengan baik (Sabhrina, 2014). Moral reasoning merupakan alasan moral yang mendasari individu dalam menentukan suatu tindakan dapat dibenarkan atau tidak. Proses penalaran moral dari tiap individu akan berbeda-beda tergantung dengan pengalaman dan intensitasnya dalam berinteraksi dengan lingkungan sosial di sekitarnya.

Hasil penelitian Ceacilia et al. (2016) menyatakan bahwa independensi mempunyai pengaruh positif terhadap kualitas audit melalui moral reasoning. Begitupun dengan Suriana (2014) menjelaskan pada penelitiannya bahwa independensi memberikan pengaruh positif terhadap kualitas audit melalui moral reasoning. Hal ini dipertegas oleh Indira (2015) dalam penelitiannya menemukan bahwa seorang auditor yang memiliki sikap independensi mampu memberikan pengaruh positif pada kualitas audit dengan moral reasoning sebagai moderasi. Berdasarkan uraian diatas, maka hipotesis yang dapat dirumuskan hasil penelitian sebagai berikut:

$\mathrm{H}_{3}$ : moral reasoning memperkuat pengaruh positif independensi pada kualitas audit. 
Berdasarkan penelusuran moderasi analisis dan hasil-hasil penelitian terdahulu maka model penelitian dapat digambarkan seperti berikut :

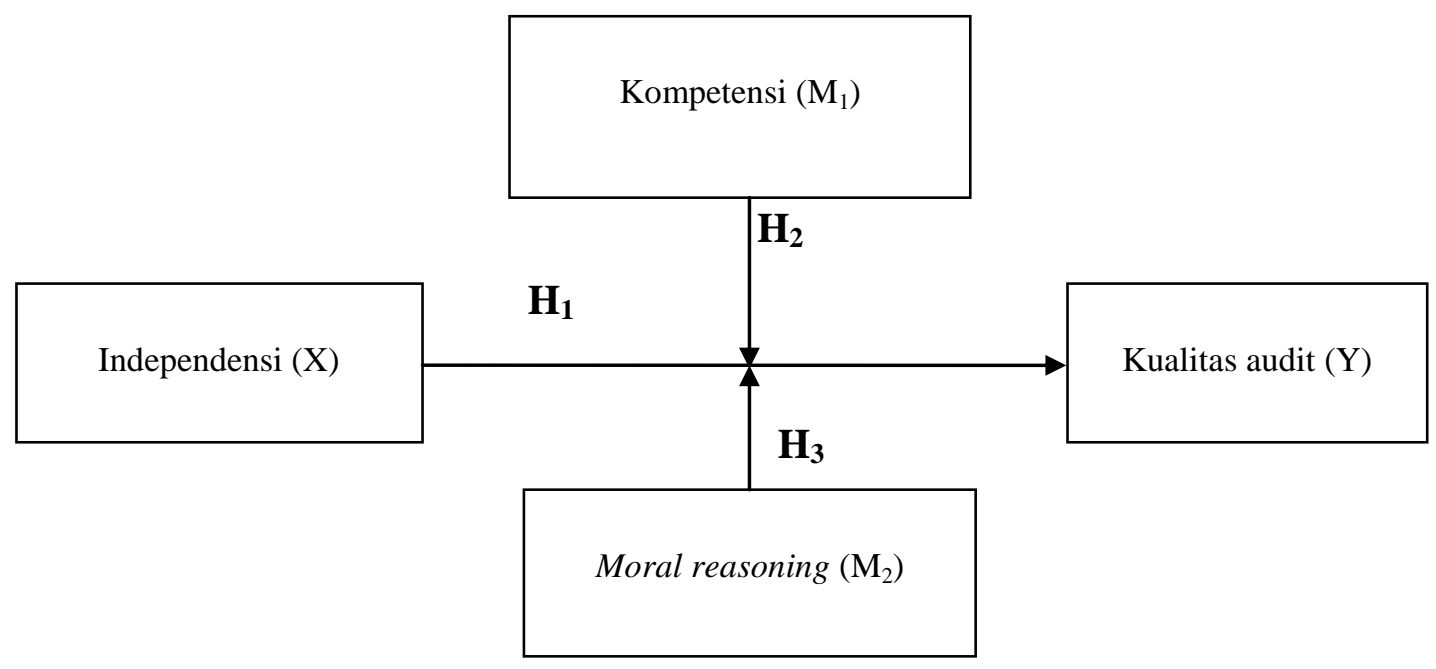

\section{Gambar 1. Kerangka Konseptual}

Sumber: Konsep penelitian, 2017

Karya ilmiah ini dilakukan dengan tujuan untuk mengetahui hubungan antara satu sampai dua variabel atau lebih. Melalui studi asosiatif dapat dibangun suatu teori yang berfungsi untuk menjelaskan, meramalkan dan mengontrol suatu gejala/fenomena hubungan antara variabel-variabel. Penelitian ini memfokuskan lokasi studi di Penelitian ini dilakukan pada Kantor Akuntan Publik yang terdapat di Bali dan terdaftar pada Institut Akuntan Publik Indonesia. Jumlah Kantor Akuntan Publik yang terdaftar pada Institut Akuntan Publik Indonesia pada tahun 2016 sebanyak tujuh kantor.

Sumber data untuk mendukung makalah studi ini seperti sumber data primer dan sekunder. Data primer melalui data yang dikumpulkan dari dengan observasi dan 
pemberian kuesioner kepada responden yaitu auditor yang bekerja di Kantor Akuntan Publik. Data sekunder sebagai pendukung adalah teori-teori pendukung, artikelartikel, serta data survey mengenai perkembangan kunjungan wisatawan.

Populasi dan Sampel

Populasi dalam penelitian ini adalah seluruh auditor yang bekerja di Kantor Akuntan Publik yang berjumlah 73 orang dengan menggunakan metode sensus (Riduwan dan Sunarto, 2007:17) sebagai berikut

Tabel 1.

\section{Jumlah Auditor Pada Kantor Akuntan Publik di Bali}

\begin{tabular}{clc}
\hline No. & \multicolumn{1}{c}{ Nama Kantor Akuntan Publik } & $\begin{array}{c}\text { Jumlah Auditor } \\
\text { (orang) }\end{array}$ \\
\hline 1. & KAP I Wayan Ramantha & 7 \\
2. & KAP Johan Malonda Mustika \& Rekan (Cab) & 10 \\
3. & KAP K. Gunarsa & 9 \\
4. & KAP Drs. Ketut Budiartha, M.Si & 12 \\
5. & KAP Drs. Sri Marmo Djogokarsono \& Rekan & 15 \\
6. & KAP Drs. Wayan Sunasdyana & 13 \\
7. & KAP Drs. Ketut Muliartha R.M \& Rekan & 7 \\
\hline Total & & 73 \\
\hline
\end{tabular}

Sumber : Data diolah, 2016

Uji Normalitas, bertujuan untuk menguji apakah suatu data berdistribusi normal atau tidak dengan model regresi memenuhi asumsi normalitas atau tidak. Uji Multikolonieritas, uji ini sebagai pedoman untuk mengetahui satu model yang bebas multikol adalah mempunyai nilai VIF (Varian Inflatation Factor) tidak lebih dari 10 dan mempunyai angka tolerance tidak kurang dari 0,1 . Uji heteroskedastisitas dalam perhitungan SPSS untuk mendeteksi adanya heteroskedastisitas yaitu dengan cara melihat ada tidaknya pola tertentu pada grafik heteroskedastisitas dimana sumbu $\mathrm{X}$ 
ISSN: 2302-8556

dan $\mathrm{Y}$ yang telah diprediksi dan sumbu $\mathrm{Y}$ adalah residual (Y prediksiYsesungguhnya) yang telah distandardized.

Teknik Analisis Moderating Regression Analysis

Teknik perhitungan dan analisis data menggunakan Moderating Regression Analysis. Moderating Regression Analysis dinyatakan dalam bentuk regresi berganda dengan persamaan mirip regressi polynomial yang menggambarkan pengaruh nonlinier (Ghozali, 2011; 47) yang dinyatakan dalam bentuk model persamaan sebagai berikut.

$$
\mathrm{Y}=\alpha+\beta_{1} \mathrm{X}_{1+} \beta_{2}\left(\mathrm{XM}_{1}\right)+\beta_{3}\left(\mathrm{XM}_{2}\right)+\mathrm{e}
$$

Keterangan:

$$
\begin{array}{ll}
\mathrm{Y} & =\text { kualitas audit } \\
\alpha & =\text { konstanta } \\
\beta_{1,}, \beta_{2}, \beta_{3} & =\text { koefisien regresi masing-masing variabel independen } \\
\mathrm{X} & =\text { independensi } \\
\mathrm{M}_{1} & =\text { kompetensi } \\
\mathrm{M}_{2} & =\text { moral reasoning } \\
\mathrm{e} & =\text { error term yaitu faktor kesalahan dalam penelitian. }
\end{array}
$$

\section{HASIL DAN PEMBAHASAN}

Uji Validitas menjelaskan sebuah instrumen dikatakan valid jika memenuhi syarat $\mathrm{r}=$ 0,3". Hasil uji validitas membukitan hasil masih-masing indikator variabel memiliki nilai person correlation lebih besar dari 0,30 . Uji reliabilitas mampu menunjukan 
sejauh mana instrument dapat dipercaya dengan nilai suatu instrumen dikatakan reliabel bila nilai Alpha Cronbach $\geq 0,6$.

Uji normalitas akan ditampilkan pada gambar menggunakan uji KolmogorovSmirnov dengan signifikansi lebih besar dari 0,05 yaitu 0,668 maka dapat disimpulkan bahwa model regresi terdistribusi secara normal. Uji Multikolinearitas dengan nilai tolerance masing-masing variabel lebih besar dari 0,1 dan nilai VIF lebih kecil dari 10, sehingga dapat disimpulkan bahwa dalam model regresi tidak terjadi multikolinearitas dan dapat digunakan dalam penelitian ini. Uji heteroskedastisitas bertujuan untuk menguji apakah model regresi terjadi ketidaksamaan varians dari residual pengamatan ke pengamatan yang lain. Hasil membuktikan nilai signifikansi masing-masing variabel lebih besar dari 0,05 yang berarti variabel tersebut bebas heteroskedastisitas. Analisis regresi moderasi teknik perhitungan dan analisis data menggunakan Moderating Regression Analysis. Moderating Regression Analysis dinyatakan dalam bentuk regresi berganda dengan persamaan mirip regresi polynomial yang menggambarkan kompetensi dan moral reasoning dalam memoderasi pengaruh independensi terhadap kualitas audit pada Kantor Akuntan Publik.

Tabel 2.

Hasil Pelaporan Analisis MRA

$\begin{array}{ccccc}\text { Model } & \begin{array}{c}\text { Unstandardized } \\ \text { Coefficients }\end{array} & \begin{array}{c}\text { Standardized } \\ \text { Coefficients }\end{array} & \text { Sig } & \begin{array}{c}\text { Hasil Uji } \\ \text { Hipotesis }\end{array}\end{array}$


ISSN: 2302-8556

E-Jurnal Akuntansi Universitas Udayana

Vol.23.1. April (2018): 240-266

\begin{tabular}{cccccc} 
& B & Std. Error & Beta & & \\
\hline (Constanta) & $-17,360$ & 17,252 & & 0,320 & \\
$\mathrm{X}_{1}$ & 2,743 & 1,203 & 2,005 & 0,028 & $\mathrm{H}_{1}$ Diterima \\
$\mathrm{XM}_{1}$ & 0,204 & 0,060 & 3,768 & 0,001 & $\mathrm{H}_{2}$ Diterima \\
& & & & & \\
$\mathrm{XM}_{2}$ & 0,150 & 0,061 & 2,393 & 0,019 & $\mathrm{H}_{3}$ Diterima \\
& & & 0,000 & & \\
Signifikansi F & & & 0,619 & & \\
R Square & & &
\end{tabular}

Sumber : Data diolah, 2016

Persamaan regresi pada Tabel 2, dapat dijelaskan untuk setiap variabel hal-hal sebagai berikut: Nilai Konstanta, yang diperoleh adalah sebesar -17,360 menunjukan bahwa apabila perubahan variabel bebas yaitu independensi, kompetensi dan moral reasoning sama dengan nol atau bersifat konstan, maka kualitas audit tidak mengalami penurunan pada Kantor Akuntan Publik Provinsi Bali. Nilai Koefisien $\beta_{1}$ yang diperoleh sebesar 2,743 menunjukan bahwa apabila independensi meningkatkan maka kualitas audit juga akan meningkat pada Kantor Akuntan Publik Provinsi Bali.

Nilai Koefisien $\beta_{2}$ yang diperoleh sebesar 0,204 menunjukan bahwa interaksi antara variabel kompetensi dan independensi bersifat positif. Artinya interaksi kompetensi memperkuat pengaruh antara independensi terhadap kualitas audit pada Kantor Akuntan Publik Provinsi Bali. Nilai Koefisien $\beta_{3}$ yang diperoleh sebesar 0,150 menunjukan bahwa interaksi antara variabel moral reasoning dan independensi bersifat positif. Artinya interaksi moral reasoning memperkuat pengaruh antara independensi terhadap kualitas audit pada Kantor Akuntan Publik Provinsi Bali.

Hasil uji statistik F pada Tabel 2, menunjukan hasil nilai siginifikansi sebesar 0,000 yang lebih kecil dari tingkat $\alpha=0,05$. Hal ini berarti variabel independensi, kompetensi dan moral reasoning secara bersamaan berpengaruh signifikan terhadap 
kualitas audit pada Kantor Akuntan Publik Provinsi Bali. Hal ini mengindikasikan bahwa model yang digunakan dalam penelitian ini layak dipergunakan.

Pengujian pengaruh secara parsial antara variabel independen dan variabel dependen digunakan uji t. Adapun hasil analisis dari uji t ini adalah sebagai berikut: Hasil perhitungan uji t dapat dilihat pada Tabel 2. Dari tabel tersebut diketahui bahwa nilai koefisien regresi $\mathrm{X}$ adalah sebesar 2,279 dengan tingkat signifikansi sebesar 0,028 lebih kecil dibandingkan dengan taraf nyata $\alpha=0,05$. Hal ini menunjukan bahwa independensi berpengaruh positif dan signifikan pada kualitas audit pada Kantor Akuntan Publik Provinsi Bali. Semakin tinggi independensi seorang auditor maka kualitas audit juga semakin meningkat. Hipotesis yang menyatakan bahwa independensi berpengaruh positif dan signifikan pada kualitas audit diterima.

Hasil perhitungan uji t dapat dilihat pada Tabel 2. Dari tabel tersebut diketahui bahwa nilai koefisien regresi $\left|Z \mathrm{ZM}_{1}\right|$ adalah sebesar 3,422 dengan tingkat signifikansi sebesar 0,001 lebih kecil dibandingkan dengan taraf nyata $\alpha=0,05$. Hal ini menunjukan bahwa kompetensi seorang auditor mampu memperkuat pengaruh positif independensi terhadap kualitas audit pada Kantor Akuntan Publik Provinsi Bali, artinya semakin baik kompetensi seorang auditor maka sikap independensi yang dimilikinya semakin baik pula sehingga mampu meningkatkan kualitas audit. Hipotesis yang menyatakan bahwa kompetensi memperkuat pengaruh positif independensi pada kualitas audit diterima. 
ISSN: 2302-8556

Hasil perhitungan uji t dapat dilihat pada Tabel 2. Dari tabel tersebut diketahui bahwa nilai koefisien regresi $\left|Z_{2 X}\right|$ adalah sebesar 2,447 dengan tingkat signifikansi sebesar 0,019 lebih kecil dibandingkan dengan taraf nyata $\alpha=0,05$. Hal ini menunjukan bahwa moral reasoning seorang auditor mampu memperkuat pengaruh positif independensi pada kualitas audit pada Kantor Akuntan Publik Provinsi Bali, artinya semakin baik sikap moral reasoning auditor maka independensi yang dimilikinya semakin baik pula sehingga mampu meningkatkan kualitas audit. Hipotesis yang menyatakan bahwa moral reasoning memperkuat pengaruh positif independensi pada kualitas audit diterima.

Pengujian koefisien determinasi $\left(\mathrm{R}^{2}\right)$ dilakukan untuk mengetahui seberapa besar variasi variabel dependent akan mampu dijelaskan oleh variabel independennya, sedangkan sisanya dijelaskan oleh sebab-sebab variabel lain di luar model (Ghozali, 2011:97). Berdasarkan Tabel 2 menunjukan bahwa nilai adjusted R square model 0,619 atau sebesar 61,9\% artinya sebesar $61,9 \%$ variasi atau perubahan kualitas audit dapat dijelaskan oleh variasi variabel dalam model tersebut yaitu independensi, kompetensi, dan moral reasoning.

Pembahasan Hasil Penelitian

Hasil uji parsial menunjukan bahwa independensi berpengaruh positif dan signifikan pada kualitas audit pada Kantor Akuntan Publik Di Bali. Hubungan antara independensi dengan pendapat hasil audit menyimpulkan bahwa auditor yang independen memberikan pendapat hasil audit lebih tepat dibandingkan auditor yang 
tidak independen (Nizarul et al., 2007). Sikap independensi yang dimaksud seorang audit bersikap transparan sehingga tidak memihak pihak manapun dalam menyusun program audit baik itu gangguan dan tekanan dari pihak internal ataupun eksternal perusahaan sehingga menghasilkan temuan audit berdasarkan subyek pekerjaan secara transparan dan akuntabel untuk kepentingan perusahaan. Pelaksanaan audit yang berkualitas tentunya di dukung oleh berbagai hal, salah satunya adalah penerimaan kompensasi yang diterima auditor, wajib bagi perusahaan untuk mengawasi pemberian kompensasi yang diterima oleh auditor yang bersifat transparan sehingga menghasilkan laporan audit yang berkualitas.

Hasil penelitian ini sama dengan penelitian Ari (2010) menunjukkan bahwa independensi berpengaruh positif pada kualitas audit. Hasil penelitian Nizarul et al. (2007) membuktikan hal yang sama dimana kualitas audit dipengaruhi secara positif oleh sikap independensi seorang auditor. Nila (2014) dalam penelitiannya menemukan bahwa seorang auditor yang memiliki sikap independensi mampu memberikan kualitas pada hasil laporan audit.

Hasil uji parsial menunjukan bahwa kompetensi mampu memperkuat atau memoderasi berpengaruh positif dan signifikan independensi pada kualitas audit pada Kantor Akuntan Publik Di Bali. Sari (2012) menjelaskan pada Standar Profesional Akuntan Publik tercantum bahwa untuk memenuhi persyaratan sebagai seorang profesional, auditor harus memiliki kompetensi, sehingga dapat disimpulkan bahwa kompetensi merupakan hal mutlak yang harus dimiliki oleh auditor. Sikap 
ISSN: 2302-8556

kompetensi seorang auditor dalam hal melakukan pelaksanaan audit selalu mengutamakan kepentingan klien memilih klien yang tepat, sehingga mampu menyelesaikan pekerjaan tepat waktu, tidak menjanjikan klien sesuatu diluar kemampuan, dan menjaga kerahasiaan hasil temuan audit klien dari pihak luar hal ini yang menjaga sikap independensi seorang auditor sehingga mampu menghasilkan laporan audit yang berkualitas.

Hasil penelitian ini sesuai dengan penelitian Nizarul et al. (2007) menunjukkan secara empiris bahwa faktor kompetensi mampu memperkuat hubungan independensi pada kualitas audit. Hasil penelitian Yunita dan Leny (2015) membuktikan hal yang sama dimana kualitas audit dipengaruhi secara positif oleh independensi yang dimoderasi oleh kompetensi yang dimiliki auditor. Abdul et al. (2014) menemukan bukti empiris bahwa kompetensi yang dimiliki oleh seorang auditor mampu memperkuat pengaruh independensi pada kualitas audit.

Hasil uji parsial menunjukan bahwa moral reasoning mampu memperkuat atau memoderasi pengaruh positif dan signifikan independensi pada kualitas audit pada Kantor Akuntan Publik Di Bali. Sabhrina (2014) menyatakan moral reasoning merupakan alasan moral yang mendasari individu dalam menentukan suatu tindakan dapat dibenarkan atau tidak. Proses penalaran moral dari tiap individu akan berbedabeda tergantung dengan pengalaman dan intensitasnya dalam berinteraksi dengan lingkungan sosial di sekitarnya sehingga mampu meningkatkan kualitas audit. Moral reasoning dalam hal ini dimaksud bagi setiap auditor wajib memiliki sikap moral 
dalam pelaksanaan audit sehingga memiliki landasan untuk menentukan sikap sebagai prinsip keadilan dalam melakukan proses pelaksanaan audit sehingga menghasilkan laporan audit yang berkualitas.

Hasil penelitian ini sesuai dengan penelitian Ceacilia et al. (2016) menyatakan bahwa independensi mempunyai pengaruh positif pada kualitas audit melalui peran moral reasoning. Begitupun dengan Suriana (2014) menjelaskan pada penelitiannya bahwa independensi memberikan pengaruh positif terhadap kualitas audit melalui moral reasoning. Hal ini dipertegas oleh Indira (2015) dalam penelitiannya menemukan bahwa seorang auditor yang memiliki sikap independensi mampu memberikan pengaruh positif pada kualitas audit dengan moral reasoning sebagai moderasi.

\section{SIMPULAN}

Melihat dan memahami pembahasan pada bab-bab sebelumnya, maka hal-hal yang dapat disimpulkan adalah independensi berpengaruh positif terhadap kualitas audit pada Kantor Akuntan Publik di Bali. Kompetensi memperkuat pengaruh positif independensi terhadap kualitas audit pada Kantor Akuntan Publik di Bali. Moral reasoning memperkuat pengaruh positif independensi terhadap kualitas audit pada Kantor Akuntan Publik di Bali.

Berdasarkan kesimpulan di atas, maka adapun saran yang dapat diberikan diharapkan dapat memberikan kontribusi praktis bagi para praktisi auditing khususnya manajemen KAP agar dapat mempertimbangkan karakteristik personal 
ISSN: 2302-8556

auditor dalam keputusan menetapkan waktu penugasan audit agar tercapai efesiensi audit tanpa mengurangi efektifitas audit. Hal ini dapat dilakukan dengan melakukan review secara terus terhadap kertas kerja auditor sehingga menghindari tekanan dari pihak manapun dalam menyusun program audit. Begitu juga para auditor sebaiknya memperhatikan pentingnya personal yang baik dalam menjalankan audit, dalam hal ini kompetensi yang dimiliki agar dapat digunakan sebaik mungkin seperti sikap dalam menentukan jumlah klien yang di audit agar menghasilkan laporan audit yang berkualitas, tidak mengecewakan klien dengan menjanjikan hal diluar kemampuan. Sikap moral reasoning yang dimiliki oleh auditor sebagai prinsip keadilan dalam melaksanakan audit sehingga memiliki landasan untuk menentukan sikap independensi yang menghasilkan laporan audit yang berkualitas.

Bagi perusahaan yang menggunakan jasa audit, harus memperhatikan ketepatan dalam pelaporan, meningkatkan pelaksanakan aktivitas penilaian dan pemeriksaan atas kebenaran data dan informasi dari sistem dan pengambilan kebijakan yang tepat, sehingga pengawasan dari auditor dalam pengumpulan bukti untuk mendukung temuan audit dapat menghasilkan laporan audit yang berkualitas untuk mempertahankan keberlangsungan hidup perusahaan.

Peneliti selanjutnya diharapkan dapat mengambil variabel lainnya selain kompetensi, moral reasoning dan independensi, seperti integritas, role stress, perilaku disfungsional dengan menerapkan di lokasi penelitian yang lain seperti perbankan, pemerintahan dan lainnya. 


\section{REFERENSI}

Abdul Halim, Sutrisno T, Rosidi, M. Achsin, 2014. Effect of Competence and Auditor Independence on Audit Quality with Audit Time Budget and Professional Commitment as a Moderation Variable. International Journal of Business and Management Invention. 3(6): h:64-74

Adnyani Nyoman, Anantawikrama Tungga Atmadja dan Trisna Herawati Nyoman, 2014. Pengaruh Skeptisme professional auditor, independensi, dan pengalaman auditor terhadap tanggung jawab auditor dalam mendeteksi kecurangan dan kekeliruan laporan keuangan (Studi Kasus pada Kantor Akuntan Publik (KAP) Wilayah Bali). Akuntansi. 2(1): h: 1-11

Alan Lovell. 2015. Moral reasoning and moral atmosphere in the domain of accounting, Accounting. Journal of Auditing \& Accountability. 8(3): h: 60-80

Arens, Alvin A. Elder, Randal J dan Beasley, Mark S, 2008. "Auditing dan Jasa Asuransi Pendekatan Terintegrasi”. Jilid 2, Edisi keduabelas, Erlangga,

Ari Kristin Prasetyoningrum, 2010. Analisis Pengaruh Independensi dan Profesionalisme Dewan Pengawas Syariah terhadap Kinerja Bank Perkreditan Rakyat Syariah di Jawa Tengah. Akuntansi Muhamadiyah. 12(1): h: 27-36

Badir Mohammed Alwan, Dr. and D. Abeer Ihsan Samara, 2013. Compliance Auditors the Rules of Professional Conduct based on International Accounting Standards. International Journal of Humanities and Social Science. 3(3): h: 105-118

Badjuri, Achmat. 2011. Faktor-Faktor yang Berpengaruh Terhadap Kualitas Audit Auditor Independen pada Kantor Akuntan Publik (KAP) di Jawa Tengah. Dinamika Keuangan dan Perbankan. 3(2): h: 183-197.

Ceacilia Sri Mindarti, Pancawati Hardiningsih, Rachmawati Meita Oktaviani. 2016. Moral Reasoning Memoderasi Kompetensi dan Independensi Terhadap Audit. Simposium Nasional Akuntansi. 11(1): h:1-25

Departemen Pendidikan dan Kebudayaan. 1988. Kamus Besar Bahasa Indonesia. Jakarta: Departemen Pendidikan dan Kebudayaan.

Dwi Putra Wahyudi, Emrinaldi Nur DP dan Julita Saidi, 2015. Hubungan Etika Profesi, Keahlian, Pengalaman, dan Situasi Audit dengan Ketepatan Pemberian Opini data Audit Laporan Keuangan Melalui Pertimbangan 
ISSN: 2302-8556

E-Jurnal Akuntansi Universitas Udayana

Vol.23.1. April (2018): 240-266

Materialitas dan Skpetisisme Profesional Auditor. Publikasi Aknuntansi. pp: $1-15$

Dwiyani Ciptana Putri dan Rasmini, Ni ketut. 2016. Fee Audit Sebagai Pemoderasi Pengaruh Auditor Switching Pada Kualitas Audit. Akuntansi Universitas Udayana. 16(3): h: 2017-2043

Emrinaldi Nur DP, Julita dan Dwi Putra Wahyudi, 2014. Pengaruh Etika, Kompetensi, Pengalaman Auditor Dan Situasi Audit Terhadap Ketepatan Pemberian Opini Audit Melalui Pertimbangan Materialitas Dan Skeptisisme Profesional Auditor. Jurnal Ilmiah STIE MDP. 3(2): h: 116-132

Ghozali, Imam. 2011. Aplikasi Analisis Multivariate dengan Program SPSS. Edisi kc-2. Semarang: Badan Penerbit Universitas Diponegoro.

Indira Januarti, Faisal. 2015. Pengaruh Moral Reasoning dan Skeptisisme Profesional Auditor Pemerintah Terhadap Kualitas Audit Laporan Keuangan Pemerintah Daerah. Simposium Nasional Akuntansi. 5(2): h:1-32

Ikatan Auditor Indonesia. 2001. Standar Profesional Auditor Publik. Jakarta: Salemba Empat.

Ikatan Akuntansi Publik Indonesia. "Kode Etik Profesi Akuntan Publik", Institut Akuntan Publik Indonesia. Jakarta, 2009.

lkhsan, Arfan. 2008. Metodologi Penelitian Auditorsi Keperilakuan. Edisi 1. Yogyakarta: Oraha Ilmu.

Ikha Zuhriatun Mufidah. 2015. Pengaruh Kompetensi, Etika, dan Fee Audit terhadap Kualitas Audit. Akuntansi. 1(5): h: 1-18

Kenneth D'Silva and Jeffrey Ridley, 2007. Internal auditing's international contribution to governance. Journal Business Governance and Ethics. 3 (2): h: $113-126$

Malem Ukur Tarigan dan Primsa Bangun Susanti. 2014. Pengaruh Kompetensi, Etika dan Fee Audit terhadap Kualitas Audit. Akuntansi. 13(1): h: 803-832

Mulyadi, 2002. Auditing. Edisi ke-6. Jakarta: Salemba Empat.

Nila Gustia, 2014. Pengaruh independensi auditor, etika profesi, komitmen organisasi dan gaya kepemimpinan terhadap kinerja auditor pemerintah (Studi Empiris Pada Auditor Pemerintah di BPKP Perwakilan Sumbar). Akuntansi. pp: 1-23 
Nizarul Alim, Trisni Hapsari dan Liliek Purwanti, 2007. Pengaruh Kompentensi dan Independensi Terhadap Kualitas Audit dengan Etika Auditor sebagai Variabel Moderasi. Simposium Nasional Akuntansi. 2(8): h:1-26

Novyarni Nelli, 2014. Influence of Internal Auditor Competence and Independence on The Quality of Financial Reporting By Municipa/ Provincial Government. International Journal of Economics, Commerce and Management. 2(10): h: 114

Paneeda Tangsakul \& Phaprukbaramee Ussahawanitchakit. 2015. Moral Reasoning of Tax Auditors in Thailand: an Empirical Investigation of The Antecedents and Consequences. Journal The Business and Management Review. 7(1): h: $134-142$

Sabhrina Kushasyandita, 2014. Pengaruh Pengalaman, Keahlian, Situasi Audit, Etika dan Gender Terhadap Ketepatan Pemberian Opini Auditor Melalui Skpetisisme Profesional Auditor (Studi Kasus Pada KAP Big Four di Jakarta). Akuntansi. pp: 1-30

Sari Ramadhanis. 2012. Pengaruh Kompetensi, Independensi dan Motivasi terhadap Kualitas Audit Pada Inspektorat. Binar Akuntansi. 1(1): h: 76-84

Sukendra, Putu, Gede Adi Yuniarta dan Anantawikrama Tungga Atmadja, 2015. pengaruh skeptisme profesional auditor, pengalaman auditor dan keahlian audit terhadap ketepatan pemberian opini oleh auditor (Studi Empiris pada Inspektorat Kabupaten Buleleng, Kabupaten Bangli dan Kabupaten Karangasem). Akuntansi. 3(1): h: 1-12

Suriana AR. Mahdi. 2014. Analisis Faktor-faktor Penentu Kualitas Audit dengan Moral Judgment Sebagai Pemoderasi. Akuntansi \& Auditing. 11(1): h: 61-82

Suyana Utama, Made. 2009. Buku Ajar Aplikasi Analisis Kuantitatif. Denpasar :Fakultas Ekonomi Universitas Udayana

Syamsuddin, I Made Sudarma, Abdul Hamid Habbe, Mediaty, 2014. The Influences Of Ethics, Independence, And Competence On The Quality Of An Audit Through The Influence Of Professional Skepticism In Bpk Of South Sulawesi, Central Sulawesi And West Sulawesi. Journal of Research in Business and Management. 2(7): h: 08-14 
ISSN: 2302-8556

E-Jurnal Akuntansi Universitas Udayana

Vol.23.1. April (2018): 240-266

Sri Trisnaningsih, 2007. Independensi Auditor dan Komitmen Organisasi sebagai mediasi pengaruh pemahaman Good Governance, gaya kepemimpinan dan budaya organisasi terhadap kinerja auditor. Simposium nasional Akuntansi, 2(1): h: $1-56$

Sugiyono. 2013. Metode Penelitian Bisnis. Bandung: CV. Alfabeta.

The Indonesia Institute For Corporate Governance. 2007. Good Corporate governance dalam Perspektif Manajemen Stratejik.

The Institute of Auditor internals. (1995). Standars for The Professional Practice of Auditor internaling. The IIA, Florida.

Toufan Taufiq Akbar Nurzaman. 2014. Pengaruh Moral Reasoning dan Skeptisisme Profesional Audit Pemerintah Terhadap Kualitas Audit Laporan Keuangan Pemerintah Daerah: Studi Pada Auditot BPK RI Kantor Perwakilan Sulawesi Tengah. Skripsi Universitas Sebelas Maret Surakarta.

Umar, Husein. 2007. Metode Penelitian untuk Skripsi dan Tesis Bisnis. Edisi Bam ke7. PT Raja Grafmdo Persada. Jakarta.

Yunita Nugraheni dan Leny Suzan. 2015. Pengaruh Kompetensi, Independensi dan Audit fee terhadap Kualitas Audit (Studi Empiris Pada Kantor Akuntan Publik Di Kota Bandung). Repository Akuntasi. 1(4): h: 1-8 